The BMJ

Cite this as: BMJ 2021;372:n717 http://dx.doi.org/10.1136/bmj.n717 Published: 15 March 2021

\section{Covid-19: Government's failure to share data and face scrutiny have undermined response, say MPs}

\author{
Elisabeth Mahase
}

The UK government's failure to share the data behind its decisions during the covid pandemic it likely to have undermined its response and placed a "needless strain on public confidence," MPs have said in a damning report. ${ }^{1}$

The Public Administration and Constitutional Affairs Committee emphasised the importance of publishing the data used to justify policy decisions and accused the government of wilfully evading scrutiny.

Looking to the next few months, the committee said the government must now provide "absolute clarity" on the data underpinning the easing of restrictions to "live up to the prime minister's commitment to 'data, not dates.”'

The government must also stop "moving the goalposts" when it comes to lockdown and tiering decisions and should outline, in its response to this report, the range of data and information it would use to lift current and future lockdowns, the committee said.

\section{Evading scrutiny}

The report criticised the government's engagement with the committee during the inquiry. It said that the minister for the Cabinet Office, Michael Gove, "declined to appear before the committee when called and ministers sent in his place were poorly briefed and unable to answer the questions put to them." Meanwhile, written responses to the committee's questions often "failed to provide the information requested."

"This is wilful evasion of parliamentary scrutiny," the report said. The committee reminded the government of its "obligation to hold itself open to scrutiny and expects each recommendation to be responded to in full."

The committee said it "expects Gove to respond to this report, clearly outlining his understanding of his own responsibilities, and the ways in which he should be held to account by Parliament."

Committee chair William Wragg said, "Delays in sharing vital data, and a reluctance to share detailed data, almost certainly hampered the local response. This over-centralisation must not be repeated ... If the government learns the right lessons and improves how it shares data with partners and the public, we can be in the best possible position to react to any future stages of the pandemic.”

The report's recommendations included that the Cabinet Office must clearly outline responsibilities for decision making before the Coronavirus Act is considered for renewal after 25 March 2021. This should include clear lines of accountability and state which minister is accountable to parliament for ensuring that key decisions are underpinned by data.

Chaand Nagpaul, the BMA's chair of council, said that his organisation had long called for ministers to be open and transparent about the reality facing the nation and to provide clarity in their decision making, which should be based on science and evidence.

“The government's decision making process has often been political rather than based on transparent facts and objectivity," he said. "We've seen a lack of openness about the actual level of PPE supplies during the first wave, with false assurances of a sufficient stockpile that was patently not the case. There have been policies regarding restrictions and tiers made without sharing statistics to underpin decisions and there was a failing to be open about SAGE's warning last September urging for a circuit breaker, which was then followed by a second wave.

"Our devastating mortality figures could in part be a result of the failure of the government to properly and openly share data, communicate accurately, and act swiftly. It is imperative that ministers' decisions on easing lockdown restrictions are based on transparent information of infection rates and vaccine efficacy and to fully honour its commitment to 'data, not dates."”

The committee's other recommendations included that:

- Ministers must ensure the data behind that statistics they quote are published and made easily accessible

- All graphics should meet the government statistical service's good practice guidelines on data visualisation and meet accessibility regulations

- Statements published on government websites must include hyperlinks or footnotes directing readers to the detailed data underpinning any

- The Ministerial Code should be strengthened so it is clear that ministers are required to abide by the UK Statistics Authority Code of Practice in their presentation of data, and

- The government must share all the available data with local areas in as much detail as possible, ideally to patient level.

The committee told the government it must state clearly whether it has accepted or rejected each recommendation and should outline its next steps, as well as giving a clear explanation for any recommendation it has rejected. "It is not sufficient numbers or statistics quoted 
for the government to 'note' a recommendation as they have done in the past," the report said.

1 House of Commons Public Administration and Constitutional Affairs Committee. Government transparency and accountability during Covid 19: the data underpinning decisions. 9 Ma 2021.

https://committees.parliament.uk/committee/327/public-administration-and-constitutional-affairscommittee.

This article is made freely available for use in accordance with BMJ's website terms and conditions for the duration of the covid-19 pandemic or until otherwise determined by BMJ. You may use, download and print the article for any lawful, non-commercial purpose (including text and data mining) provided that all copyright notices and trade marks are retained. 